\title{
Seroepidemiology of Leptospirosis in Domestic Animals from India
}

\author{
Sophia Inbaraj*, Shiv Varan Singh and Pallab Chaudhuri \\ Division of Veterinary Bacteriology and Mycology, ICAR-Indian Veterinary Research \\ Institute, Bareilly-243122, India \\ *Corresponding author
}

\begin{tabular}{|l|}
\hline K e y w o r d s \\
Leptospirosis, \\
Cattle, Sera, \\
Epidemiology, \\
Goats, Serovar \\
\hline Article Info \\
\hline $\begin{array}{l}\text { Accepted: } \\
\text { 04 August } 2019 \\
\text { Available Online: } \\
\text { 10 September } 2019\end{array}$ \\
\hline
\end{tabular}

\section{A B S T R A C T}

An epidemiological study was done to study leptospirosis in domestic animals. Sera samples collected from various farm animals (cattle- 331, goat-88, horses -9 , dogs -10) from various parts of the country were examined by Microscopic agglutination test. A panel of 12 reference strains was used in the study. Out of the 438 samples, 27 samples showed agglutination for Leptospira antigens yielding an overall positivity of $6.16 \%$. Study revealed that $6.34 \%$ cattle and $5.68 \%$ goat sera were positive for leptospiral antibodies. Javanica, hebdomadis and grippotyphosa were the common serovars against which antibodies could be detected. Only one clinically suspected dog sample was found to be positive for the serovar grippotyphosa. The equine samples screened were negative for leptospiral agglutinins. The seroepidemiology studies revealed decreasing trend of leptospirosis in northern states and Andaman Nicobar Islands in comparison to the previous years.

\section{Introduction}

Leptospirosis is an important zoonotic disease transmitted to humans. The disease is highly prevalent in tropical and sub-tropical climate of south East Asian countries (Vijayachari et al., 2008). In the event of climatic change and global warming, leptospirosis remains an important disease of concern which is influenced by hot and humid weather and excessive flooding. The organism follows a complex epidemiological pattern in urban, rural and developed environmental setup.
Under rural settings, increased agriculture, animal husbandry water logging are considered as risk factors whereas in urban settings of developing countries, poor sanitation, ill managed sewage settings favour rodent population and increase the disease risk. In developed countries, recreational activities such as swimming and water sports favour the chances of disease occurrence (Lau et al., 2010). Domestic animals such as cattle, sheep, goats, pigs, horses act as reservoir hosts of the organism. Among the domestic animals, classical leptospirosis occurs in canine species 
characterized by pulmonary, hepatic and renal involvement (Goldstein, 2010). Acute cases in cattle are characterized by fever, hemolytic anemia, hemoglobinuria, abortion and jaundice whereas chronic cases are characterized by reproductive failure (Koizumi and Yasutomi, 2012). In equines, leptospirosis results in acute respiratory failure in foals, abortion and recurrent uveitis in horses (Ye et al., 2014). In goats, leptospirosis is associated with fever, hemoglobinemia, hemoglobinuria, reproductive disorders and birth of weak kids (Lilenbaum et al., 2008 a, Lilenbaum et al., 2008b). The major cause of economic losses associated with leptospirosis is due to abortions, still birth and birth of weak young ones. The major route of transmission to humans is through water, rodents and livestock/pets (Mwachui et al., 2015). Therefore, routine screening of these animals for presence of leptospiral antibodies is essential to keep the disease status in an endemic area at vigil. Microscopic agglutination test remains the gold standard test for serological diagnosis of leptospirosis in epidemiological studies. The procedure suffers from various pitfalls such as reduced sensitivity, necessity to handle live organisms, laborious test procedure and need for a technical expertise for interpretation. Moreover, in case of animals obtaining double sera samples (during acute and convalescent phase) were quite difficult (Rajapakse et al., 2015). But in case of epidemiological screening single serum sample with a titre cutoff of $\geq 100$ is enough to conclude the positivity regardless of the endemicity of the region for leptospirosis (Sabarinath et al., 2018).

\section{Materials and Methods}

\section{Sample collection}

Serum samples from domestic animals $(\mathrm{n}=$ 438) such as cattle $(n=331)$, goats $(n=88)$, horses (9) and dogs $(n=10)$ received by the Leptospira laboratory, IVRI from December, 2017- March, 2019 were included in the current study. The sera samples were received from Andaman and Nicobar Islands, Himachal Pradesh, Uttarakhand, Odisha, Maharashtra and Uttar Pradesh regions of the country.

The sera samples were stored at $-20^{\circ} \mathrm{C}$ until further examination.

\section{Bacterial strains}

A panel of 12 leptospiral serovars namely Australis (Ballico), Autumnalis (Akiyami A), Ballum (S102), Ballum (Mus 127), Canicola (Hond Utrecht IV), Grippotyphosa (Moskva V), Hardjo (Hardjobovis), Hebdomadis (Hebdomadis), Icterohaemorrhagiae (RGA), Javanica (Veldrat. Bat. 46), Pomona (Pomona), Pyrogenes (Salinem) and Tarassovi (Perepelitsin) were included in the current study.

\section{Microscopic Agglutination test (MAT)}

The serum samples were diluted to 1:50 in phosphate buffer saline (PBS) and equal volume of 12 Leptospira live antigens were added in 96 welled round bottomed microtitre plates to make a final serum concentration of $1: 100$. The samples were incubated at $29^{\circ} \mathrm{C}$ for 2-3 hrs. The antigen-antibody interactions were observed under 10X dark field microscope. However, the sera samples showing 50\% agglutination at 1:100 titre is considered as positive. The positive sera were further titrated to find the end titer.

\section{Statistical analysis}

The chi-square test was performed to analyze the level of significance in presence of leptospira among different animal species using MS excel. P-values of $<0.05$ was considered statistically significant. 


\section{Results and Discussion}

Out of the 438 sera samples received, horse and dog sera samples were from clinically suspected cases. The sera samples from cattle and goats were sent for routine surveillance purposes. Totally, 27 samples $(6.16 \%)$ were found to be positive for leptospiral agglutinins. Among the positive cases, serovar Javanica was reported in majority $(\mathrm{n}=8)$ of the cases $(29.6 \%)$ followed by serovar Hardjo $(\mathrm{n}=6 ; 22.2 \%)$, Hebdomadis $(\mathrm{n}=5 ; 18.51 \%)$, serovar Grippotyphosa $(\mathrm{n}=4 ; 14.81 \%)$ and serovar Pomona $(n=3 ; 11.11 \%)$. Out of the 331 cattle samples, 21 sera $(6.34 \%)$ were harbouring leptospiral agglutinins. In goats, 5 out of 88 samples came positive $(5.68 \%)$ for anti-leptospira antibodies. Out of the 10 sera samples from clinically suspected dogs, only one was observed to be positive for serovar Grippotyphosa (10\%). The statistical analysis revealed $\mathrm{p}=0.8$ which showed that there is no significant association between anti-leptospira antibodies among different animal species. Table 1 depicts the prevalence rate of leptospirosis in different animal species in the current study.

Leptospirosis is one of the neglected tropical diseases affecting human beings, wild and domestic animals. In India, the disease is endemic in coastal belts such as Andaman and Nicobar Islands, Tamil Nadu, Kerala, Karnataka, Odisha, certain parts of Maharastra and southern districts of Gujarat (Shiva Kumar, 2008). Burriel et al., (2003) reported $11.8 \%$ positivity to leptospiral agglutinins in farmed animals and domestic dogs in Greece. The seroprevalence studies conducted in Thailand from 2010-2014 revealed seropositivity of $3.7 \%$ in humans, $24.8 \%$ in buffaloes, $28.1 \%$ in cattle, and $11.3 \%$ in pigs. Ranarum and Shermani were the predominant serovars reported in livestock (Chadsuthi et al., 2017). Study conducted in our laboratory during the past years from samples collected across Indian states (1995-2008) revealed the seroprevalence rate of $5.4 \%$ in buffaloes, $7.5 \%$ in cattle, $12,5 \%$ in sheep, $14.6 \%$ in horses and $15.9 \%$ in dogs (Srivastava, 2008). The seroprevalence studies conducted in various laboratories across India in bovines for the past 5 years revealed the presence of $8.4 \%$ leptospiral agglutinins in Rohilkhand region of Uttar Pradesh (Sachan et al., 2012), 42.5\% in Odisha (Balamurugan et al., 2013), 12.8\% in Gujarat (Patel et al., 2014), $42.1 \%$ in Andaman and Nicobar Islands (Sunder et al., 2017) and $41 \%$ in Tamil Nadu (Bojiraj et al., 2017). Their studies revealed that endemic areas revealed significantly higher seropositivity than non-endemic areas. In our study, we observed $6.34 \%$ seropositivity in cattle samples. Our studies revealed comparatively lower seropositivity than previous studies. The difference may be due to the spatial and temporal factors which indirectly influence the Leptospira prevalence and infection. Leptospirosis in goat population has been understudied throughout the world. Vihol et al., (2017) reported 25\% antileptospiral antibodies in goat population in south Gujarat region of India. Recently, Sabarinath et al., (2018) studied the seroepidemiology of leptospirosis in goats from various agro-climatic zones of India and observed an overall $17.88 \%$ seropositivity. Serovars such as Pyrogenes, Icterohaemorrhagiae and Grippotyphosa were the common serovars observed during the study. In our study too, we could observe $6 \%$ seropositivity out of 88 goat samples which is comparatively lower compared to the previous studies. However, the number of goat samples was very less in order to arrive at a final conclusion. In our study, we detected only one positive serum from canine clinical case for serovar Grippotyphosa. Serological and isolation studies in canine species from Indian state of Kerala revealed $36.36 \%$ seropositivity with Australis and Pomona as the prevalent serovars (Soman et al., 2014). Patil et al., 
(2014b) reported $17.5 \%$ seroprevalence in canine species in Mumbai whereas Vijayanand et al., (2008) reported $62.5 \%$ seropositivity in Chennai. These studies revealed that seropositivity of leptospirosis is comparatively higher in endemic areas.

Table.1 Prevalence of leptospirosis in different animal species

\begin{tabular}{|l|l|l|l|l|l|}
\hline $\begin{array}{l}\text { S. } \\
\text { no }\end{array}$ & $\begin{array}{l}\text { Animal } \\
\text { species }\end{array}$ & $\begin{array}{l}\text { No of animals } \\
\text { screened }\end{array}$ & Seropositive & $\begin{array}{l}\text { Prevalence } \\
\mathbf{\%}\end{array}$ & Serovars \\
\hline $\mathbf{1}$ & Cattle & 331 & 21 & 6.34 & $\begin{array}{l}\text { Javanica, Hardjo, } \\
\text { Hebdomadis, Australis, } \\
\text { Pyrogenes, } \\
\text { Grippotyphosa, Ballum, } \\
\text { Pomona }\end{array}$ \\
\hline $\mathbf{2}$ & Goat & 88 & 5 & 5.68 & $\begin{array}{l}\text { Pomona, } \\
\text { Icterohaemorrhagiae, } \\
\text { Grippotyphosa, Javanica }\end{array}$ \\
\hline $\mathbf{3}$ & Horses & 9 & & & \\
\hline $\mathbf{4}$ & Dogs & 10 & 1 & 10 & - \\
\hline
\end{tabular}

$\mathrm{P}=0.8$; Non-significant

The serum samples screened for leptospirosis were from landlocked regions northern part of India except for Andaman and Nicobar Islands. Northern India was non endemic to leptospirosis. The study revealed an overall reduction in seroprevalence of leptospirosis (6\%) in the year 2018-2019 comparison to the other studies conducted in the country. Similar trend observed in human leptospirosis (6.47\%) in northern India during 2014-2018 (Agrawal et al., 2018) also validate the results of the current study.

\section{Disclosure Statement}

No potential conflict of interest was reported by the authors

\section{Acknowledgements}

The authors acknowledge The Director, ICAR-Indian Veterinary Research Institute for providing necessary facilities to carry out the research. The authors highly acknowledge the faculty, Zoonoses Research Laboratory, TANUVAS, India for providing Leptospira reference strains to carry out the current research. The authors are thankful to Mr. Jamal Khan and Mr. Shubham Kumar, Divisional staffs, ICAR-IVRI for helping in maintenance of Leptospira cultures.

\section{References}

Agrawal SK, Chaudhry R, Gupta N, Arif N, Bhadur T. 2018. Decreasing trend of seroprevalence of leptospirosis at All India Institute of Medical Sciences New Delhi: 2014-2018. J Family Med Prim Care. 7: 1425-1428.

Balamurugan V, Thirumalesh SRA, Sridevi $\mathrm{R}$, Mohandoss N, Govindaraj G, Hemadri D, Gajendragad MR, Rahman H. 2013. Seroprevalence of bovine leptospirosis in Odisha, India. World Journal of Veterinary Sciences, 1: 1-7.

Bojiraj M, Porteen K, Gunaseelan L, Kannan S. 2017. Seroprevalence of Leptospirosis in Animals and Its Public Health Significance. Int J Livest Res. 7(11): 220-226. 
Burriel AR, Dalley C, Woodward MJ. 2003. Prevalence of Leptospira species among farmed and domestic animals in Greece. Vet Rec. Aug 2: 146-148.

Chadsuthi S, Bicout DJ, Wiratsudakul A, Suwancharoen D, Petkanchanapong W, Modchang C, et al., (2017). Investigation on predominant Leptospira serovars and its distribution in humans and livestock in Thailand, 2010-2015. PLoS Negl Trop Dis. 11(2): e0005228.

Goldstein, R.E. 2010. Canine leptospirosis. Vet Clin Small Anim. 40: 1091-1101.

Koizumi N, Yasutomi I. 2012. Prevalence of leptospirosis in farm animals. Jpn J Vet Res. 60(S): 55-58.

Lau CL, Smythe LD, Craig SB, Winstein P. 2010. Climate change, flooding, urbanization and leptospirosis. Fuelling the fire? Trans R Soc Trop Med Hyg. 104: 631-638.

Lilenbaum W, Varges R, Brandao FZ, Cortez A, de Souza SO, Brandao PE, Richtzenhain LJ, Vasconcellos SA. 2008b. Detection of Leptospira spp. in semen and vaginal fluids of goats and sheep by polymerase chain reaction. Theriogenology. 69(7): 837-842.

Lilenbaum W, Varges R, Medeiros L, Cordeiro AG, Cavalcanti A, Souza GN, Richtzenhain L, Vasconcellos SA. 2008a. Risk factors associated with leptospirosis in dairy goats under tropical conditions in Brazil. Res Vet Sci. 84: 14-17.

Mwachui MA, Crump L, Hartskeerl R, Zinsstag J, Hattendorf J. 2015. Environmental and Behavioural Determinants of Leptospirosis Transmission: A Systematic Review. PLoS Negl Trop Dis 9(9): e0003843. doi:10.1371/journal. pntd.0003843.

OIE. 2014. Manual of Diagnostic Tests and Vaccines for Terrestrial Animals, ch. 2.1.12. Leptospirosis (accessed April
28, 2018) Available at: http://www.oie.int/

fileadmin/Home/eng/Health_standards/t ahm/2.01.12_LEPTO.pdf.

Patel JM, Vihol PD, Prasd MC, Kalyani IH, Raval JK, Patel KM, Thirumalesh SRA, Balamurugan V. 2014a. Seroepidemiological pattern of leptospirosis in bovine of South Gujarat, India. Vet. World, 7(11): 999-1003.

Patil,D., Dahake, R., Mukherjee, S., Chowdhary, A., Deshmukh, R. 2014b. Prevalence of leptospirosis among dogs and rodents and their possible role in human leptospirosis from Mumbai, India. Indian Journal of Medical Microbiology, 32(1): 64-67.

Rajapakse S, Rodrigo C, Handunnetti SM, Fernando SD. 2015. Current immunological and molecular tools for leptospirosis: diagnostics, vaccine design, and biomarkers for predicting severity. Ann Clin Microbiol Antimicrob. 14(2).

Richtzenhain L, Vasconcellos SA. 2008a. Risk factors associated with leptospirosis in dairy goats under tropical conditions in Brazil. Res Vet Sci. 84: 14-17.

Richtzenhain LJ, Vasconcellos SA. 2008 b. Detection of Leptospira spp. in semen and vaginal fluids of goats and sheep by polymerase chain reaction. Theriogenology. 69(7): 837-842.

Sabarinath T, Behera SK, Deneke Y, Atif Ali S, Kaur G, Ashok Kumar, Ravi Kumar G, Senthil Kumar K, Sinha DK, Verma MR, Srivastava SK, Chaudhuri P. 2018. Serological evidence of anti-Leptospira antibodies in goats in various agro climatic zones of India. Small Rumin Res. 169: 74-80.

Sachan N, Nautiyal B, Singh VP, Sabarinath T, Agarwal RK. 2012. Seroprevalence of leptospirosis in the animals in 
Rohilkhand region of Uttar Pradesh, India. IJAVMS. 6(6): 461-465.

Shiva Kumar, S. 2008. Leptospirosis-Current scenario in India. Medicine update. 18:799-810.

Soman M, Jayaprakasan V, Mini M. 2014. Epidemiological study on human and canine leptospirosis in Central and North Kerala. Vet World. 7(10): 759764.

Srivastava SK. 2008. Current status of leptospirosis in India in animals and humans. Indian J Vet Pathol. 32(2): 179-186.

Vihol PD, Jignesh MP, Jatin HP, Mahesh CP, Vijendra HD, Kalyani IH, Tyagi KK.
2017. Seroepidemiology of caprine leptospirosis in south Gujarat region of India. Int J Curr Microbiol Appl Sci. 6: 1599-1608.

Vijayachari P, Sugunan AP, Shriram AN. 2008. Leptospirosis: an emerging global public health problem. J.Biosci. 33(4): 557-569.

Ye C, Yan W, McDonough PL, McDonough SP, Mohamed H, Divers TJ, Chang YF, Yang Z. 2014. Serodiagnosis of equine leptospirosis by Enzyme Linked Immunosorbent Assay using four recombinant protein markers. Clin. Vaccine Immunol. 21(4): 478-483.

\section{How to cite this article:}

Sophia Inbaraj, Shiv Varan Singh and Pallab Chaudhuri. 2019. Seroepidemiology of Leptospirosis in Domestic Animals from India. Int.J.Curr.Microbiol.App.Sci. 8(09): 37-42. doi: https://doi.org/10.20546/ijcmas.2019.809.006 